University of South Florida

DIGITAL COMMONS

Digital Commons @ University of

@ UNIVERSITY OF SOUTH FLORIDA

South Florida

School of Geosciences Faculty and Staff

Publications

School of Geosciences

3-1994

\title{
Aftershocks of the 13 May 1993 Shumagin Alaska Earthquake
}

\author{
Zhong Ludwig \\ Universtiy of Alaska Fairbanks \\ Max Wyss \\ Universtiy of Alaska Fairbanks \\ Guy Tytgat \\ Universtiy of Alaska Fairbanks \\ Stephen R. McNutt \\ Universtiy of Alaska Fairbanks, smcnutt@usf.edu \\ Scott Stihler \\ U. S. Geological Survey
}

Follow this and additional works at: https://digitalcommons.usf.edu/geo_facpub

Part of the Earth Sciences Commons

\section{Scholar Commons Citation}

Ludwig, Zhong; Wyss, Max; Tytgat, Guy; McNutt, Stephen R.; and Stihler, Scott, "Aftershocks of the 13 May 1993 Shumagin Alaska Earthquake" (1994). School of Geosciences Faculty and Staff Publications. 265.

https://digitalcommons.usf.edu/geo_facpub/265

This Article is brought to you for free and open access by the School of Geosciences at Digital Commons @ University of South Florida. It has been accepted for inclusion in School of Geosciences Faculty and Staff Publications by an authorized administrator of Digital Commons @ University of South Florida. For more information, please contact digitalcommons@usf.edu. 


\section{Aftershocks of the 13 May 1993 Shumagin Alaska earthquake}

Zhong Lu, Max Wyss, Guy Tytgat, and Steve McNutt

Geophysical Institute, Universtiy of Alaska Fairbanks

Scott Stihler

U. S. Gcological Survey, Fairbanks

Abstract. The 13 May $1993 \mathrm{M}_{\mathrm{s}} 6.9$ Shumagin earthquake had an aftershock sequence of 247 earthquakes with magnitudes greater than or equal to 1.5 by 1 June 1993. Of these aftershocks, 79 were located by using S-P travel times at the only two stations within $570 \mathrm{~km}$ of the mainshock epicenter. The rupture area inferred from the aftershocks is about $600 \mathrm{~km}^{2}$ and we estimate for the mainshock a mean fault displacement of $1.0 \mathrm{~m}$ and a 28 bar stress drop. The magnitude-frequency plots give a b-value for the aftershock sequence of about 0.4 , which is low compared to the background value of approximately 0.8 . The decay of the aftershock sequence followed the modified Omori law with a p-value of 0.79 , which is also lower than the typical values of about 1.1 observed in Alaska. Both of these facts can be interpreted as indicating relatively high ambient stress in the Shumagin seismic gap and the possibility that the 13 May earthquake was a foreshock to a larger gap-filling event to occur within the next few years.

\section{Introduction}

The Shumagin Islands region of the Alaska-Aleutian arc is located along the westernmost portion of the Alaska Peninsula. Based on the recent large and great earthquakes and on historically documented accounts of earthquakes occurring near the Shumagin Islands, this region has been identified as a seismic gap [Davies et al., 1981; Jacob, 1984; Nishenko and Jacob, 1990] (Figure 1). The Shumagin seismic gap has a probability $P Z 60 \%$ of rupturing in the next 20 years(19882008) [Nishenko and Jacob, 1990], and should be capable of supporting an earthquake as large as $\mathrm{M}_{\mathrm{w}} 8.3$ if it ruptures in its entirety [Boyd and Lerner-Lam, 1988]. However, Boyd and Lemer-Lam [1988] and Estabrook and Boyd [1992] suggested that the Shumagin gap can be divided into three segments, which may rupture separately (Figure 1).

A debate has been prompted about the seismic potential in the Shumagin gap by the lack of significant strain accumulation in the geodetic networks. Lisowski et al. [1988] and Savage [1992] argued that the Shumagin segment of the plate boundary may not have the potential for a gap-filling earthquake, while Beavan and Gilbert [1992] and Dmowska et al. [1992] proposed models that explain the lack of measured strain accumulation and yet allow for the possibility of a gapfilling earthquake.

In this paper, the rupture extent of the 13 May 1993 earthquake is estimated from the aftershock area, and the bvalue and p-value are compared to those of other subduction earthquakes.

\section{Spatial Distribution of Aftershocks}

The aftershock locations were estimated from S-P times. Because Sand Point (SDN) and Mt. Dutton (DTN) are the only two seismograph stations within $570 \mathrm{~km}$ of the epicenter

\section{Copyright 1994 by the American Geophysical Union.}

Paper number $94 \mathrm{GL} 00332$

0094-8534/94/94GL-00332\$03.00
(Figure 1), we confine the depths of all aftershocks to that of the main shock, $32 \mathrm{~km}$. This assumption is valid for aftershocks located on the plate interface, because its dip angle in the Shumagin area is very small [Taber et al., 1991]. However, it introduces a location error less than or equal to 12 $\mathrm{km}$ to the north for aftershocks located in the wedge above the plate interface. Thus, the S-P times used to constrain the epicenters were determined using the following equation:

$$
t_{s-p}=\left(\frac{1}{v_{s}}-\frac{1}{v_{p}}\right) \sqrt{\Delta^{2}+h^{2}}=\frac{1}{c} \sqrt{\Delta^{2}+h^{2}}
$$

where, $t_{s-p}$ is the $S-P$ time interval, $v_{p}$ and $v_{s}$ are $P$ and $S$ velocity respectively, $\Delta$ is the epicentral distance, and $h$ is the depth assumed to be $32 \mathrm{~km}$ [Jaume, personal communication]. The constant, $c$, in the equation (1) was determined empirically for both stations, using earthquakes which occurred during 1991. At that time the Shumagin seismograph network was still in existence and furnished accurate locations. The constant $(\mathrm{c}=9.7 \mathrm{~km} / \mathrm{sec})$ was adjusted separately for the two stations to yield locations based on $t_{s-p}$ that best agreed with the known epicentral locations from the network data.

The maximum location error is estimated to be $5 \mathrm{~km}$ in longitude and $12 \mathrm{~km}$ in latitude, for aftershocks that may have happened at $3 \mathrm{~km}$ depth instead of $32 \mathrm{~km}$, as assumed in our location procedure. The maximum error may be as large as 11 $\mathrm{km}$ in longitude and $15 \mathrm{~km}$ in latitude if the reading errors of $0.6 \mathrm{sec}$ for the Mt. Dutton paper recordings and $0.3 \mathrm{sec}$ for the Sand Point digitized seismograms are also taken into account.

The locations of the 79 best located aftershocks, which could be analyzed for the period 13 May through 1 June 1993, are shown in Pigure 1. These events were large enough to be recorded at Mt. Dutton, and yet small enough not to saturate the instrument at Sand Point. The locations extend to both sides along the plate boundary from the main shock epicenter [Jaume, personal communication]. Some of the aftershocks appear to be located north, i.e. down dip, from the mainshock epicenter. Virtually none of them are located up dip.

The dimensions of the rupture area may be reasonably estimated from the extent of the aftershock activity immediately after the mainshock [e.g. Kanamori, 1970]. However, such estimates may be too large because of the uncertainty in aftershock locations and because of the temporal expansion of the aftershock area [Kanamori and Anderson, 1975]. Therefore, we used the aftershocks of the first 4 days, before the $m_{b} 5.5$ aftershock, to define the rupture area (Figure 2), estimating it as $43 \mathrm{~km}$ long and $14 \mathrm{~km}$ wide, approximately. The $600 \mathrm{~km}^{2}$ rupture area of this $\mathrm{M}_{\mathrm{s}} 6.9$ earthquake agrees well with the value expected based on the magnitude-area relation $M=\log A+4.15$ [Wyss, 1979].

The stress drop for the main shock is calculated as 28 bar, using the scalar moment $2.9 \times 10^{26}$ dyne-cm [U.S. Department of the Interior, Geological Survey, NEIC Quick Epicenter Determination]. This value is very close to the average of 30 bars for subduction earthquakes [Kanamori and Anderson, 1975]. The average displacement across the fault plane is obtained as approximately $1.0 \mathrm{~m}$. This amount of slip may be accumulated in approximately 14 years, if we assume that the entire relative plate motion rate of $7.4 \mathrm{~cm} /$ year [Davies et al., 1981 ] is stored as elastic strain. 


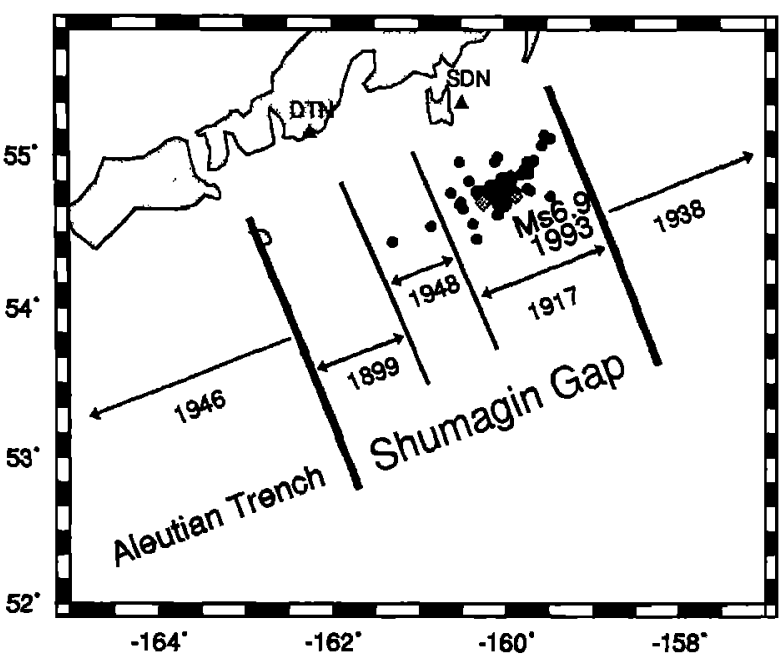

Fig. 1. Map of the Shumagin Islands area, Alaska. The 13 May 1993 Shumagin mainshock, two largest aftershocks, and other aftershocks through 1 June 1993 are shown as the large dot, rectangles, and small dots respectively. The triangles are the only two seismograph stations SND and DTN (standing for Sand Point and Mt. Dutton respectively) within about $570 \mathrm{~km}$ of the epicenter. The vertical thin lines and the horizontal thin lines with arrow(s) define the rupture zones of the 1946, 1899, 1948,1917 , and 1938 earthquakes. The two vertical thick lines define the Shumagin seismic gap. The horizontal thick line delineates the plate boundary. It seems that the 13 May 1993 earthquake re-ruptured approximately the same segment that ruptured in the 1917 earthquake.

\section{Magnitude Distribution of Aftershocks}

The magnitudes of the 247 aftershocks $(M \geq 1.5)$ that occurred in the first 19 days were estimated from paper records at Mt. Dutton station using coda duration by the following equation (Lahr,1989):

$$
\mathrm{M}=-1.15+2.0 \log _{10} \mathrm{D}+0.007 \mathrm{Z}
$$

where, $\mathrm{D}$ is coda duration in seconds and $\mathrm{Z}$ is depth of the aftershock in $\mathrm{km}$. For aftershocks with magnitudes greater than 3.5, we adopted the magnitudes assigned by the National Earthquake Information Center as well as the Alaska Earthquake Information Center. The magnitude distribution as a function of time is shown in Figure 3. The two events that stand out as the largest aftershocks occurred on 17 May $\left(m_{b}=5.5\right)$ and 25 May $\left(m_{b}=6.0\right), 4$ and 12 days, respectively, after the mainshock. These largest aftershocks were separated by a lull in seismicity (Figure 3). They occurred in the central part of the aftershock zone, about 11 and $14 \mathrm{~km}$ from the mainshock epicenter (Figure 1).

The magnitude-frequency relationship is plotted in Figure 4a. A straight-line fit of these data yields a b-value of $0.42 \pm 0.03(M \geq 1.5)$. The cumulative plot of $M \geq 2.0$ gives $a b-$ value equal to $0.40 \pm 0.02$ and the $M \geq 3.0$ plot results in $\mathrm{b}=0.32 \pm 0.01$. Compared with the long term regional $\mathrm{b}$-value of $0.75 \pm 0.06(2.5 \leq \mathrm{M}<6.0)$ and $0.85 \pm 0.09(3.0 \leq \mathrm{M}<5.0)$ in the Shumagin area [Jacob and Hauksson, 1983], the 1993 aftershock sequence has a lower than average $b$-value.

\section{Temporal Distribution of Aftershocks}

The temporal distribution of aftershocks obeys the modified Omori law, which can be expressed as the following equation:

$$
R(t)=\frac{k}{(t+c)^{p}}
$$

where, $R(t)$ is the rate of occurrence of aftershocks, and $k, c$, and $p$ are three constants. Of the three parameters, the p-value is the most important. It measures the decay rate of aftershocks and its value may depend on the properties of the faulting surface.

The two p-values, and the relationships between cumulative number of earthquakes and the time after the main shock were obtained by the maximum likelihood estimate (Figure 5). The $p$-value after the $M_{s} 6.9$ main shock up to the $m_{b} 6.0$ aftershock is $0.79 \pm 0.06$. The decay rate of the earthquake sequence after the $m_{b} 6.0$ aftershock shows a $p$-value of $0.66 \pm 0.22$.

Seismic quiescence appears to have preceded the largest aftershock $\left(m_{b}=6.0\right)$. The six days between approximately 150 and 300 hours after the mainshock contain only a few aftershocks (Figure 3 ). The seismicity rate during this period falls clearly below the modified Omori law fit up to the largest aftershock (Figure 5). A seismicity rate lower than expected during the aftershock sequence may be used to predict large aftershocks as proposed by Matsu'ura [1986]. Although we did not evaluate quantitatively the quiescence during the 13 May 1993 aftershock sequence, it appears that this may be an example surpporting Matsu'ura's [1986] hypothesis.

\section{Discussion and Conclusions}

The 13 May 1993 Shumagin earthquake had a rupture 43 $\mathrm{km}$ long and $14 \mathrm{~km}$ wide. It seems to have re-ruptured approximately the segment of the Shumagin gap that ruptured in 1917 [Estabrook and Boyd, 1992]. But, because the 1917 Shumagin earthquake was more poorly documented [Estabrook and Boyd, 1992], the information on magnitude, location and size of the rupture zone of this earthquake is uncertain. Therefore, we do not know whether the same or neighboring segments ruptured in 1917 and 1993.

The extremely low b-value of the 13 May 1993 Shumagin earthquake can be interpreted to suggest that the 13 May earthquake may be a foreshock sequence to a larger main shock, based on the hypothesis that foreshocks have low bvalues [e.g. Wyss and Lee, 1973; Smith 1986; Imoto, 1991; Trifu and Radullian, 1991]. However, some earthquake sequences in subduction zones that are not foreshocks do also have low b-values. For example, the 6 April $1974 m_{b}=6.0$ Shumagin earthquake sequence had a b-value of 0.34 [House and Boatwright, 1980]; the 14 February $1983 \mathrm{M}_{\mathrm{s}}=6.3$ Shumagin earthquake sequence had a b-value equal to about 0.3 [Taber and Beavan, 1986]; and the 21 June $1987 \mathrm{M}_{\mathrm{s}}=6.1$ Shumagin earthquake sequence had a b-value of 0.42 (Figure 4b). The aftershock sequences of all these Shumagin earthquakes had low b-values, but no larger earthquakes followed. Thus, we conclude that Shumagin earthquake sequences may have low b-values in general.

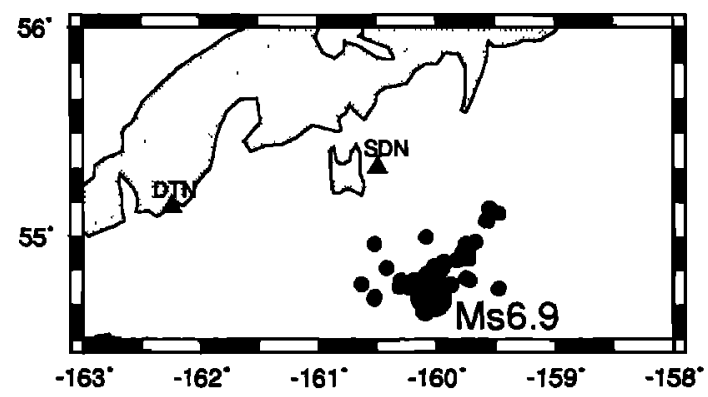

Fig. 2. Epicenter map of the better located aftershocks (small dots) during the first 4 days after the 13 May 1993 Shumagin earthquake (large dot). The triangles mark the two seismograph stations SND and DTN. These 49 aftershocks were used to estimate the rupture area of 13 May 1993 Shumagin earthquake. 


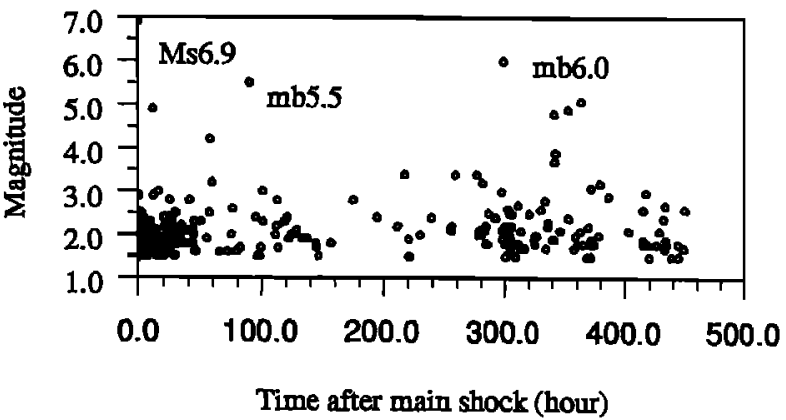

Fig. 3. Magnitude distribution as a function of time after the 13 May 1993 Shumagin earthquake. The magnitudes are estimated from coda durations measured at the $160 \mathrm{~km}$ distant Mt. Dutton station (Figure 1 and 2).

The number of aftershocks observed for this Shumagin sequence is significantly lower than the average number expected for an earthquake with $\mathrm{M}_{\mathrm{s}}=6.9$. Based mainly on Western United States data, one would expect about $46 \pm 17$ aftershocks with $M \geq 4$ [McNutt and Toppozada, 1990], but only 8 with magritude $M \geq 4$ are observed in the 13 May Shumagin earthquake sequence. The 13 May 1993 Shumagin
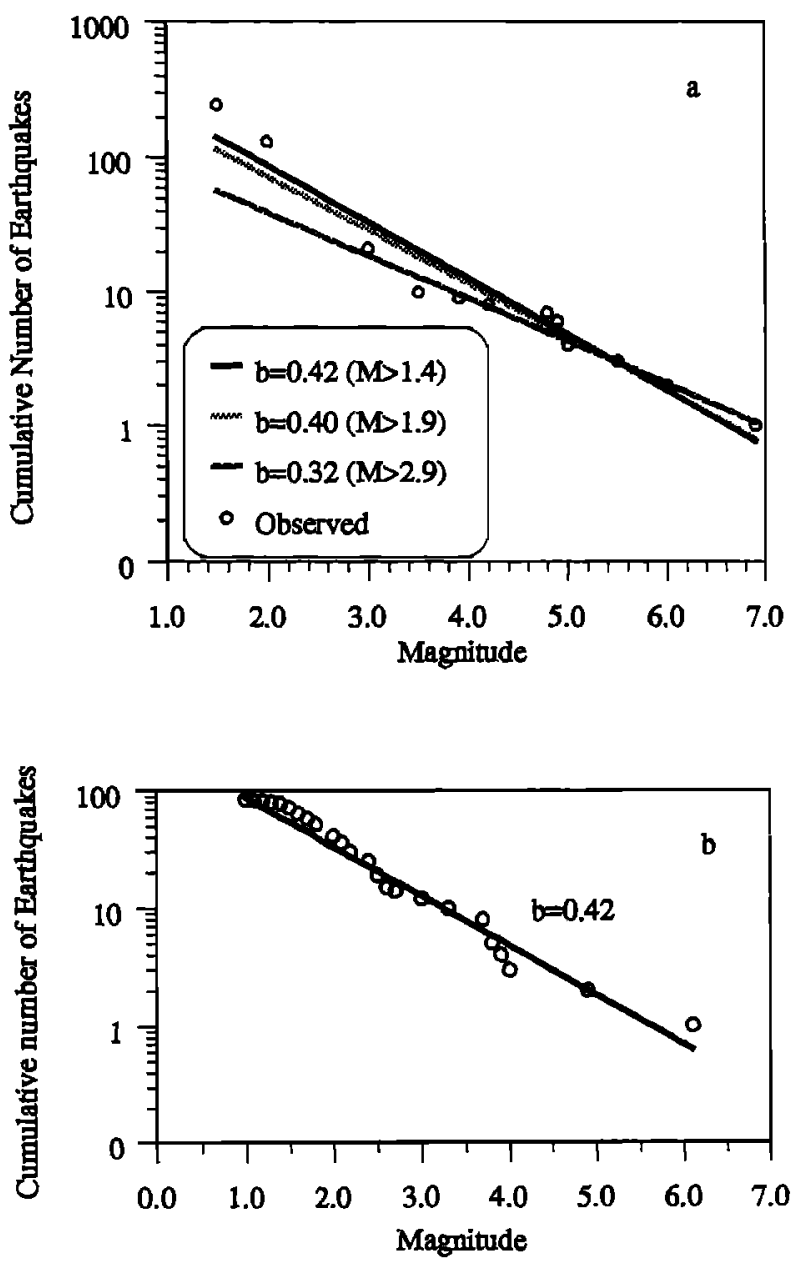

Fig. 4. Cumulative number of aftershocks of the 13 May 1993 and 21 June 1987 Shumagin earthquakes as a function of magnitude are shown in (a) and (b) respectively. The b-value estimates are based on straight-line fittings.

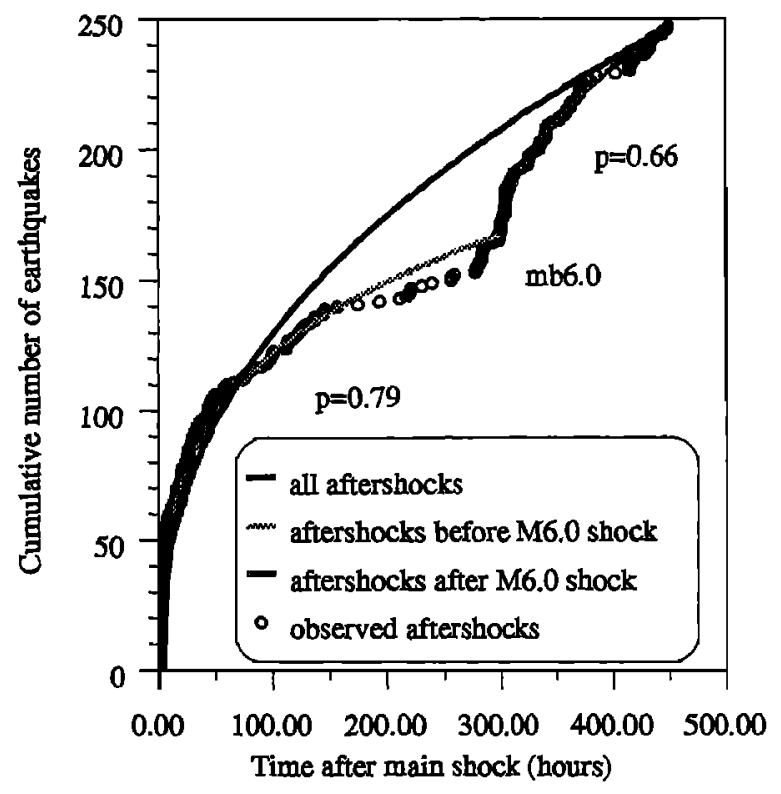

Fig. 5. Cumulative number of aftershocks of the 13 May 1993 Shumagin earthquake as a function of time after the main shock. The modified Omori law decay functions are fit separately for the time before and after the largest $\left(m_{b}=6.0\right)$ aftershocks, as well as for the entire period.

earthquake sequence clearly fits the pattern of deficiency in numbers of aftershocks noted for Alaska and Eastern Pacific plate boundaries by Singh and Suarez [1988].

The p-value of $0.7 \sim 0.8$ in the 13 May 1993 Shumagin earthquake sequence is lower than that of previous earthquakes in different parts of Alaska (e.g. $p=1.05,1.05$, 1.13 for the sequences of March 1957, April 1958, and July 1958, respectively, [Utsu, 1961], $\mathrm{p}=1.14$ for the sequence of March 1964 [Page, 1968], and $p=0.87$ for the sequence of May 1986 [Engdahl et al, 1989]). The p-value of the $13 \mathrm{May}$ Shumagin earthquake implies a relatively high stress in the Shumagin gap based on the hypothesis that the temporal decay of aftershock activity with time reflects a decrease in stress with time [Page, 1968] owing to dissipation through the occurrence of aftershocks and through plastic flow in the aftershock region [Mogi, 1962]. The 13 May 1993 earthquake may also be interpreted as a foreshock sequence if we accept the interpretation that $p \leq 1$ is for foreshock sequences, $p \geq 1$ is for double mainshock sequences, and $p \gg 1$ for aftershock sequences of a single largest earthquake [Liu, 1984]. Altematively, the p-value of the 1993 Shumagin earthquake may imply that the Shumagin subduction zone has a relatively low temperature and high velocity, if the relationship between low p-value and the low temperature in the source volume, hypothesized by Mogi [1967] and Kisslinger and Jones [1991], using Japanese and Southern California earthquake data respectively, is valid in Alaska.

This earthquake activity with a low b-value in an area of increasing moment release [Bufe et al., 1992; Jaume and Estabrook, 1992; Bufe, personal communication; Jaume, personal communication] prompted us to install six temporary seismographs in the area. These three component stations were supplied for one month by the RAMP program of IRIS. Three of these stations were supplemented with strong ground motion instruments supplied by K. Jacob. After their removal, we installed five seismographs in the Shumagin gap area to monitor the seismicity over the next several years, because we believe that this area continues to have one of the highest probabilities for a gap-filling earthquake. 
Acknowledgments. This work was supported by the Wadati endowment at the Geophysical Institute, University of Alaska Fairbanks, by the Alaska Earthquake Information Center, and by the Alaska Volcano Observatory. We thank G. Abers for suggesting that we calculate the $b$-values of previous Shumagin aftershock sequences and for supplying the necessary catalog. We also thank $C$. Kisslinger for a program for estimating maximum likelihood p-values.

\section{References}

Beavan, J. and L. Gilbert, Vertical crustal deformation in the Shumagin seismic gap, Alaska, Proceedings, Wadati conference on great suduction earthquake, 141, University of Alaska, 1992,

Boyd, T. M. and A. L. Lerner-Lam, Spatial distribution of turn-of-century seismicity along the Alaska-Aleutian arc, Bull. Seism. Soc. Am., 78,636-650, 1988.

Bufe, C. G., S. P. Nishenko, and D. J. Varnes, Clustering and potential for large earthquakes in the Alaska-Aleutian region, Proceedings, Wadati conference on great suduction earthquake, 129, University of Alaska, 1992.

Davies, J., L. Sykes, L. House, and K. H. Jacob, Shumagin seismic gap, Alaska peninsula: history of great earthquakes, tectonic setting, and evidence for high seismic potential, J. Geophys. Res., 86, 3821-3855, 1981.

Dmowska, R., G. Zheng, J. R. Rice and L. C. Lovison-Golob, Stress transfer, seismic phenomena and seismic potential in the Shumagin seismic gap, Alaskka, Proceedings, Wadati conference on great suduction earthquake, 150, University of Alaska, 1992.

Engdahl, E. R. and S. B. Kisslinger, Teleseismically recorded seismicity before and after the May 7,1986, Andreanof Islands, Alaska, earthquake, J. Geophys. Res., 94, 1548115498, 1989.

Estabrook, C. H. and T. M. Boyd, The Shumagin Islands, Alaska, earthquake of 31 May 1917, Bull. Seism. Soc. Am., 82, 755-773,1992.

House, L. and J. Boatwright, Investigation of two high stress drop earthquakes in the Shumagin seismic gap, Alaska, $J$. Geophys. Res., 85, 7151-7165,1980.

Imoto, M., Changes in the magnitude-frequency b-value prior to large $(M \geq 6.0)$ earthquakes in Japan, Tectonophysics, 193, 311-325, 1991.

Jacob, K. H., and E. Hauksson, A seismotectonic analysis of the seismic and volcanic hazards in the Pribilof Islandseastern Aleutian Islands region of the Bering Sea, Lamont-Doherty Geological Observatory of Columbia University, 224 pp, 1983.

Jaume, S. C. and C. H. Estabrook, Accelerating seismic moment release and outer-rise compression: possible precursors to the next great earthquake in the Alaska peninsula region, Geophys. Res. Lett., 19, 345-348, 1992.

Kanamori, H., Synthesis of long-period surface waves and its application to earthquake source studies-Kurile Islands earthquake of October 13, 1963, J. Geophys. Res., 75, 5011-5027, 1970.

Kanamori, H., and D. L. Anderson, Theoretical basis of some empirical relations in seismology, Bull. Seism. Soc. Am., 65, 1073-1095, 1975.

Kisslinger, C. and L. M. Jones, Properties of aftershock sequences in Southern California, J. Geophys. Res., 96, 11947-11958, 1991.
Lahr, J., Hypoellipse/version 2.0: A computer program for determining local earthquake hypocentral parameters, magnitude, and first motion pattern, U.S.G.S. Open File Report 89-116, 1989.

Lisowski, M. and J. C. Savage, W. H. Prescott, and W. K. Gross, Absence of strain accumulation in Shumagin seismic gap, Alaska, 1980-1987, J. Geophys. Res., 93, 7909, 1988.

Liu, Z. R., Earthquake frequency and prediction, Bull. Seism. Soc. Am. 74, 255-265, 1986.

Matsu'ura R. S., Precursory quiescence and recovery of aftershock activity before some large aftershocks, Bull. Earthq. Res. Inst. Tokyo Univ., 61, 1-65, 1986.

McNutt, S. R. and T. R. Toppozada, Seismological aspects of the 17 October earthquake, California Department of Conservation Special publication 104, 11-27, 1990.

Mogi, K., On the time distribution of aftershocks accompanying the recent earthquakes in and near Japan, Bull. Earthq. Res. Inst. Tokyo Univ., 40, 107-124, 1962.

Mogi, K., Earthquakes and fractures, Tectonophysics, 5, 3555,1967

Nishenko, S. P. and K. H. Jacob, Seismic potential of the Queen Charlotte-Alaska-Aleutian seismic zone, $J$. Geophys. Res., 95,2511-2532, 1990.

Page, R., Aftershocks and microaftershoks of the great Alaska earthquake of 1964, Bull. Seism. Soc. Am., 58, 1131-1168, 1968.

Savage, J. C., The argument against the Shumagin seismic gap hypothesis, Proceedings, Wadati conference on great suduction earthquake, 140, University of Alaska, 1992.

Singh, S. $K$. and G. Suarez, Regional variation in the number of aftershocks $\left(m_{b} \geq 5\right)$ of large, subduction-zone earthquakes $\left(\mathrm{M}_{\mathrm{w}} \geq 7.0\right)$, Bull. Seism. Soc. Am., 78, 230$242,1988$.

Smith W. D., Evidence for precursory changes in frequencymagnitude b-value, Geophys. J. R. astr. Soc., 86, 815-838, 1986.

Taber, J. J. and J. Beavan, 14 February 1983 earthquake sequence in the Shumagin Islands, Alaska, Bull. Seism. Soc. Am., 76, 1588-1596, 1986.

Taber, J. J., S. Billington, and E. R. Engdahl, Seismicity of Aleutian Arc, chapter 3, Decade Map Volume 1, The Geology of North America, 1991.

Trifu C. I. and M. Radulian, Frequency-magnitude distribution of earthquakes in Vrancea: Relevance for a discrete model, J. Geophys. Res., 96, 4301-4311, 1991.

Utsu, T. A., A statistical study on the occurrence of aftershocks, Geophys. Mag., 30, 521-605, 1961.

Wyss, M., Estimating maximum expectable magnitude of earthquakes from fault dimensions, Geology, 7, 336-340, 1979.

Wyss, M. and W. H. K. Lee, Proceedings of the conference on tectonic problems of San Andres Fault system, Stanford University, 24, 1973.

Z. Lu, S. McNutt, S. Stihler, G. Tytgat, and M. Wyss, Geophysical Institute, University of Alaska Fairbanks, Fairbanks, AK 99775.

(Received: August 9, 1993;

Revised: October 14, 1993;

Accepted: October 29, 1993.) 